УДК 378.016:614.8

DOI https://doi.org/10.26661/2522-4360-2021-2-21

\title{
МОДЕЛЬ ГОТОВНОСТІ СТУДЕНТІВ ДО ОСОБИСТОЇ БЕЗПЕКИ ВІД ШКІДЛИВОї ЗВИЧКИ
}

\author{
Іванчук А. В. \\ кандидат педагогічних наук, \\ дочент кафедри образотворчого, декоративного мистеитва, \\ технологій та безпеки життєдіяльності \\ Вінницький державний педагогічний університет \\ імені Михайла Кочююбиського \\ вул. Острозького, 32, Вінниия, Украӥна \\ orcid.org/0000-0002-6996-1403 \\ anatolij1196@gmail.com
}

\begin{abstract}
Ключові слова: пиячттво, безпека від пияцтвва, якісний аналіз, феномени пиячтвва, структурно-функиіональна модель.
\end{abstract}

Дослідження процесу формування готовності студентів до особистої безпеки від шкідливої звички показало, що психологічні явища як феномени алкогольних епізодів у малих групах, їх інтерпретація не використовується у навчальній дисципліні «Безпека життєдіялності та основи охорони праці». Традиційна концепція зміни алкогольних установок студентів на антиалкогольні не витримує критики через націленість на зміну народних звичаїв і традицій використання спиртних напоїв на свято та в печалі. Мета цього дослідження полягає у формуванні уявлення про особливості моделювання процесу формування готовності студентів до особистої безпеки від шкідливої звички. Це дослідження мало описовий характер i складалося із змістово-теоретичного i системно-структурного аналізу шляхів модернізації змісту навчального матеріалу з безпеки життєдіяльності, організації процесу моделювання безпечної поведінки молоді, сутності формування позитивної алкогольної установки у процесі соціалізації молоді, чинників ризику та шкідливих чинників побутового пияцтва, етапів розвитку побутового пияцтва до появи алкоголної залежності, основних психологічних феноменів пияцтва в малих группах, структурно-функціональних компонентів моделі готовності студентів до особистої безпеки від шкідливої звички, критеріїв сформованості структурних i функціональних компонентів моделі, змістових характеристик показників сформованості функціональних компонентів моделі. Результати дослідження показали, що розуміння студентами смислів психологічних феноменів пияцтва в малих групах відповідає сучасній парадигмі розвитку особистості як основи модернізації змісту, методів і форм навчання безпеки життєдіяльності. Теоретичне значення проведеного дослідження полягає в розробленні структурно-функціональної моделі, на основі якої буде організований процес формування готовності студентів до особистої безпеки від шкідливої звички. Практичне значення проведеного дослідження полягає в розробленні критеріїв і показників сформованості компонентів моделі, а також змістових характеристик показників сформованості функціональних компонентів моделі. 


\title{
THE MODEL OF STUDENT'S READINESS FOR PERSONAL SAFETY FROM A BAD HABIT
}

\author{
Ivanchuk A. V. \\ Candidate of Pedagogical Sciences, \\ Associate Professor at the Department of Fine and Decorative Art, Technology and Life Safety \\ Vinnytsia Mykhailo Kotsiubynskyi State Pedagogical University \\ Ostrozkoho str., 32, Vinnytsia, Ukraine \\ orcid.org/0000-0002-6996-1403 \\ anatolij1196@gmail.com
}

Key words: drunkenness, safety from drunkenness, qualitative analysis, phenomena of drunkenness, structuralfunctional model.

\begin{abstract}
Studies of the process of forming students' readiness for personal safety from bad habits have shown that psychological phenomena as phenomena of alcoholic episodes in small groups, their interpretation is not used in the discipline "Life Safety and Fundamentals of Occupational Safety". The traditional concept of changing students' alcohol attitudes to anti-alcohol does not stand up to criticism due to the focus on changing folk customs and traditions of alcohol consumption on holidays and in mourning. The purpose of this study is to form an idea of the features of modeling the process of forming students' readiness for personal safety from a bad habit. This study was descriptive and consisted of content-theoretical and system-structural analysis of ways to modernize the content of educational material on life safety, organization of the process of modeling safe behavior of young people, the essence of forming a positive alcohol attitude in the process of socialization of youth, risk factors and harmful factors of domestic drunkenness. stages of development of domestic drunkenness to alcohol dependence, the main psychological phenomena of drunkenness in small groups, structural and functional components of the model of students' readiness for personal safety from bad habits, criteria of formation of structural and functional components of the model, semantic characteristics of indicators of functional components of the model. The results of the study showed that students' understanding of the meanings of psychological phenomena of drunkenness in small groups corresponds to the modern paradigm of personality development as a basis for modernization of content, methods and forms of life safety training. The theoretical significance of the study in the development of structural and functional model, based on which the process of forming the readiness of students for personal safety from bad habits will be organized. The practical significance of the study in the development of criteria and indicators of the formation of the components of the model, as well as the content characteristics of the indicators of the formation of the functional components of the model.
\end{abstract}

Постановка проблеми. У навчальній програмі дисципліни «Безпека життєдіяльності та основи охорони праці» ставиться вимога сформувати у студентів фахову компетентність щодо здійснення майбутньої професійної діяльності з врахуванням ризику виникнення небезпек [7]. Однак у студентів молодших курсів ще не сформовані фахові компетентності, тому ця вимога є лише добрими намірами. Підвищити грамотність населення з безпеки життєдіяльності можливо за умови модернізації навчання безпеки [3], а іiі основою стане компетентнісний підхід [7]. У сучасних умовах безпека життєдіяльності формується на основі парадигми розвитку особистості студента та концепції культури безпеки життєдіяльності [8].

Формувати безпечну поведінку підлітків рекомендується на основі структурної моделі [2]. Л. Семенець і Р. Васільєвою до структурної моделі добавлено такі функціональні компоненти, як вміння ідентифікувати небезпеки та виконувати превентивні дії [13]. О. Нагайчук зазначені компетентності відносить до здоров'язберігаючих [11]. Критерієм безпечної поведінки людини буде адекватне сприйняття небезпеки [9]. Головний мотив безпеки залежить від ступеня значущості потреби в безпеці для людини [10]. Відома модель із 
такими структурними компонентами: мотиваційним, інформаційним, діяльнісним, емоційно-ціннісним, пошуковим, а також із функціональними компонентами - діагностичним, проектним, стимулюючим, комунікативним, організаторським i оцінювальним [14] взята нами за основу розроблення власної моделі формування готовності студентів до особистої безпеки від шкідливої звички.

Вживання спиртних напоїв є частиною народних звичаїв і традицій [16]. М. Пулькін стійкість звичаїв і традицій розкриває в низці народних приказок, наприклад [12, с. 5]: «На радості випити, а горе запити»; «Чого тверезий не скаже, п'яний розв'яже»; «Вино пий, дружину бий, нічого не бійся» [12, с. 6] тощо. Масштаби зловживання спиртними напоями (до 1 млн залежних від алкоголю осіб в Україні станом на 2017 рік [6, с. 63]) створюють загрозу для саморозвитку та самореалізації молоді [6]. А. Іванчуком з'ясована сутність механізму формування алкогольної залежності [4] та обгрунтовано використання наративного методу для пояснення смислів психологічних феноменів пияцтва [5].

Мета статті - розкриття особливостей моделі формування готовності студентів до особистої безпеки від шкідливої звички.

Виклад основного матеріалу дослідження. Загроза від побутового пияцтва переважно не усвідомлюється, тому з'являється брак безпеки та небезпечна поведінка людей. Джерело небезпечної поведінки людей - не у відсутності знань про небезпеку, наприклад як у випадку про нітратне забруднення овочів і фруктів, а в наявності позитивних життєвих знань. Знання запозичуються підростаючими поколіннями 3 народних звичаїв і традицій у процесі їхньої соціалізації. У свідомості молоді існує переважно позитивна інформація про фармакологічну дію алкогольних напоїв. На відміну від концепції заміни алкогольної установки на антиалкогольну [15], яка, на нашу думку, неефективна через спрямованість на зміну народних звичаїв i традицій, ми пропонуємо концепцію смислів алкогольних епізодів. Концепція смислів алкогольних епізодів відповідає сучасній парадигмі розвитку особистості. Незнання молоддю смислів культурологічних і психологічних фактів процесу побутового пияцтва $\epsilon$ джерелом небезпеки, яка реалізується через нераціональну поведінку. Отже, системотворчим чинником особистої безпеки будуть знання про смисли культурологічних і психологічних фактів процесу побутового пияцтва. Смисли формуватимуть суб'єктивне усвідомлення наявності протидії небезпеці та відчуття безпеки [9].

Алкогольна залежність формується під впливом чинників ризику та шкідливих чинників побутового пияцтва [1]. Чинниками ризику будуть: позитивна установка на вживання спиртних напоїв; належність до малої групи 3 позитивними установками на вживання спиртних напоїв; некритичне ставлення до народних традицій і звичаїв. До шкідливих чинників відносять частоту алкогольних епізодів та кількість спожитих спиртних напоїв [1]. За концепцією прийнятного ризику досягти особистої безпеки від шкідливої звички можливо шляхом мінімізації вказаних чинників.

Основа структурно-функціональної моделі формування готовності студентів до особистої безпеки від шкідливої звички буде складатися 3 мотиваційного, інформаційного і ціннісного структурних компонентів, а також діагностичного, оцінювального і компоненту прийняття рішення (функціональні складники). Критеріями сформованості структурних компонентів будуть: рівень мотивації (показники розуміння цілей і завдань формування поведінки особистої безпеки від шкідливої звички); ціннісне ставлення (показник сприйняття цінностей особистої безпеки); сформованість знань (показник засвоєння знань 3 особистої безпеки), а критеріями сформованості функціональних компонентів будуть: здатність до діагностики соціальних проблемних ситуацій (показник уміння розв'язувати аналітико-рефлексивні навчальні завдання); здатність до оцінювання стану особистої безпеки (показник уміння розв'язувати оцінювальні навчальні завдання); здатність до прийняття рішення щодо раціональної поведінки (показник уміння розв'язувати навчальні завдання із прийняття рішення).

Ми відрізняли шкідливу звичку (пияцтво) від хвороби (алкоголізм) та структурували зміст навчання навколо поняття шкідливої звички. Відомо, що шкідлива звичка трансформується та призводить до алкоголізму. Трансформація шкідливої звички пов'язана 3 розвитком у людини алкогольної потреби. У розвитку алкогольної потреби Е. Бехтель розрізняє такі етапи: випадкове пияцтво; помірне пияцтво; систематичне пияцтво; звичне пияцтво та алкоголізм [1]. Випадкове i помірне пияцтво зумовлене первинною установкою, сформованою народними звичаями i традиціями. Систематичне i звичне пияцтво зумовлене вторинною установкою, сформованною досвідом вживання спиртних напоїв, який відкриває людині феномен алкогольної ейфорії. Вторинна установка стає базовою для подальшого розвитку алкогольної потреби. Розвиток вторинної установки призводить до формування динамічного алкогольного стереотипу - психологічного ядра алкоголізму [1].

Переважно пияцтво пов'язане 3 малими групами, тому в навчальному процесі необхідно розкрити низку психологічних феноменів пияцтва на різних етапах його розвитку: самокорекцію поведінки у випадку особистісного конфлікту на 
етапах випадкового і помірного пияцтва; ефект обумовлення (підсилення ейфорії або зменшення інтенсивності емоційного напруження на етапах систематичного і звичного пияцтва); пускові чинники (рілізери) алкогольного епізоду на етапах систематичного i звичного пияцтва; механізми психологічного захисту на етапах систематичного і звичного пияцтва.

Аналітико-рефлексивні навчальні завдання призначені для аналізу поведінкових проблемних ситуацій у малих групах із метою діагностики ознак конкретного феномену пияцтва на основі міжособистісної рефлексії для постановки оцінювальних навчальних завдань. Основними аналітико-рефлексивними уміннями студентів, сформованими під час розв'язування цього типу навчальних завдань, будуть: пізнання поведінки інших людей; інтерпретація їхньої поведінки.

Оцінювальні навчальні завдання призначені для визначення особистісних ризиків, характерних у ситуації конкретного феномену пияцтва. Основними уміннями студентів, сформованими під час розв'язування цього типу навчальних завдань, будуть: оцінка поведінки членів малої групи; прогнозування подальшого розвитку процесу побутового пияцтва.

Навчальні завдання із прийняття рішення призначені для визначення характеру раціональної поведінки щодо конкретного феномену пияцтва в малій групі. Основними уміннями студентів, сформованими під час розв'язування цього типу навчальних завдань, будуть: прийняття рішення про раціональну кількість спожитих спиртних напоїв; прийняття рішення про власну частоту епізодів пияцтва або про вихід із малої групи.

Висновки. Отже, формування готовності студентів до особистої безпеки від шкідливої звички буде ефективним за умови використання концепції смислів алкогольних епізодів. Концепція смислів алкогольних епізодів узгоджується із сучасною парадигмою розвитку особистості студентів та концепцією культури безпеки життєдіяльності. Під час iii реалізації у викладанні навчальної дисципліни «Безпека життєдіяльності та основи охорони праці» створюються умови для розвитку пізнавальної сфери й особистісних якостей студентів та відповідної суб'єкт-суб'єктної взаємодії в навчальному процесі. Пошукове поле інформації щодо алкогольних епізодів звужується до феноменів пияцтва в малих групах. Інформація про феномени пияцтва в малих групах використовується для наповнення структурно-функціональної моделі формування готовності студентів до особистої безпеки від шкідливої звички. Запропоновані структурні і функціональні компоненти моделі та критерії і показники їх сформованості у студентів мають теоретичне і практичне значення. Новим і перспективним напрямом у формуванні функціональних компонентів моделі $€$ використання підходу, в основі якого є розроблення системи спеціальних навчальних завдань. Перспективи подальших досліджень структурно-функціональної моделі формування готовності студентів до особистої безпеки від шкідливої звички полягають в обгрунтуванні змістових характеристик рівнів сформованості підготовки студентів та у підготовці і проведенні педагогічного експерименту.

\section{ЛIТЕРАТУРА}

1. Бехтель Э.Е. Донозологические формы злоупотребления алкоголем: монография. Москва: Медицина, 1986. 272 с.

2. Васильева Р.Е. Модель готовности студентов к формированию безопасного поведения подростков. Вектор науки Тольяттинского государственного университета. Серия: Педагогика, психология. 2012. № 1. C. 87 - 90. URL: https://journal.tltsu.ru/rus/index.php/VNSPP/issue/view/83 (дата звернення: 17.07.2021).

3. Єрічева Т.Ю. Становлення та розвиток безпеки життєдіяльності як науки. Молодий вчений. 2017. № 9.1. С. 56-59.

4. Іванчук А.В. Розкриття механізму формування соціальної небезпеки на прикладі алкогольної залежності як дидактична умова стимулювання пізнавальної навчальної діяльності студентів при вивченні навчальної дисципліни «Безпека життєдіяльності». Сучасні інформаційні технології та інновачійні методики навчання в підготовиі фахівиів: методологія, теорія, досвід, проблеми. 2015. Вип. 41. С. 311-316.

5. Іванчук А.В. Відбір змісту навчального матеріалу про шкідливу звичку для навчальної дисципліни «Безпека життєдіяльності та основи охорони праці». Педагогічні науки. 2020. № 92. С. 49-54.

6. Казаков О.А. Сучасний стан проблеми підліткового алкоголізму. Світ медицини та біології. 2017. № 2(60). С. 63-65.

7. Кобилянська I.M., Кобилянський О.В. Аналіз категорійно-поняттєвого апарату 3 безпеки життєдіяльності. Наукові записки Бердянського державного педагогічного університету. Серія: Педагогічні науки. 2015. Вип. 3. С. 102-108.

8. Костенок П.И., Коняхина Г.П. Философия безопасности как методологического основание педагогического решения проблем обеспечения безопасности. Проблемы современного 
образования. 2020. № 5. С. 19-30. URL: https://cyberleninka.ru/article/n/filosofiya-bezopasnosti-kakmetodologicheskoe-osnovanie-pedagogicheskogo-resheniya-problem-obespecheniya-bezopasnosti (дата звернення: 10.07.2021).

9. Костюк М. Формування особистості безпечного типу поведінки. Zrównoważony rozwój Debiut naukowy 2011. Racibórz, 2012. C. 269 - 276. URL: http://www.debiut.buzek.pl/wp-content/ uploads/2018/02/Debiut2011.pdf (дата звернення: 16.07.2021).

10. Лапенко Т.Г. Мотивація в охороні праці - тільки примусом проблеми не вирішити. Інноваційні аспекти системи безпеки праці, захисту інтелектуальної власності: матеріали II Всеукр. наук.-практ. інтернет-конф. м. Полтава, 29-30 березня, 2017 р. Полтава: ПДАА, 2017. С. 5-8.

11. Нагайчук О.В. Формування компетентностей з охорони праці та безпеки життєдіяльності у майбутніх учителів технологій у процесі фахової підготовки. Проблеми підготовки сучасного вчителя. 2018. № 18. С. 241- 250.

12. Пулькин М.В. Феномен пьянства в XIX начале XX вв.: проблемы осмысления (по материалам Европейского Севера России). Studia Humanitatis. 2017. № 4.14 c. URL: http://st-hum.ru/sites/st-hum. ru/files/pdf/pulkin 5.pdf (дата звернення: 05.07.2021).

13. Семенець Л.М., Васильєва Р.Ю. Компетенції студентів закладів вищої освіти з безпеки життєдіяльності: змістовий аспект. Науковий вісник Ужгородського університету. Серія «Педагогіка. Сочіальна робота». 2019. Вип. 1 (44). С. 165-168.

14. Спіріна Т.П. Формування професійної культури майбутніх соціальних педагогів у навчальновиховному процесі вищого навчального закладу: автореф. дис. ...канд. пед. наук: 13.00.04. Житомир, 2009. 22 с.

15. Христук ОЛ. Проблема алкогольної адикції у сучасні вітчизняній психології. Науковий вісник Львівського держсавного університету внутрішніх справ. Серія психологічна. 2012. Вип. 2 (2). С. 104-112.

16. Sulima R. Antropologia codziennosci. Krakow: Wydawnictwo Uniwersytetu Jagiellonskiego, 2000. 194 s.

\section{REFERENCES}

1. Bekhtel E.E. (1986) Donozologicheskie formy zloupotrebleniia alkogolem: monografiia [Pre-nosological forms of alcohol abuse]. Moscow: Medicina. $272 \mathrm{p}$.

2. Vasileva R. u. (2012) Model gotovnosti studentov k formirovaniiu bezopasnogo povedeniia podrostkov [A model of students' readiness for the formation of safe behavior in adolescents]. Vector of science of Togliatti State University. Series: Pedagogy, Psychology. Vol. 1. P. 87-90.

3. (2017) [Formation and development of life safety as a science]. Young scientist. Vol. 9.1. P. 56-59.

4. Ivanchuk A.V. (2015) Rozkryttia mekhanizmu formuvannia sotsialnoi nebezpeky na prykladi alkoholnoi zalezhnosti yak dydaktychna umova stymuliuvannia piznavalnoi navchalnoi diialnosti studentiv pry vyvchenni navchalnoi dystsypliny «Bezpeka zhyttiediialnosti» [Disclosure of the mechanism of formation of social danger on the example of alcohol dependence as a didactic condition of stimulation of cognitive educational activity of students at studying of educational discipline "Life safety"]. Modern information technologies and innovative teaching methods in training: methodology, theory, experience, problems. Vol. 41. P. 311-316.

5. Ivanchuk A.V. (2020) Vidbir zmistu navchalnoho materialu pro shkidlyvu zvychku dlia navchalnoi dystsypliny «Bezpeka zhyttiediialnosti ta osnovy okhorony pratsi» [Selection of the content of educational material about a bad habit for the discipline "Life safety and basics of labor protection"]. Pedagogical sciences. Vol. 92. P. 49-54.

6. Kazakov O.A. (2017) Suchasnyi stan problemy pidlitkovoho alkoholizmu [The current state of the problem of adolescent alcoholism]. The world of medicine and biology. Vol. 2 (60). P. 63-65.

7. Kobylianska I.M., Kobylianskyi O.V. (2015) Analiz katehoriino-poniattievoho aparatu z bezpeky zhyttiediialnosti [Analysis of the categorical-conceptual apparatus for life safety]. Scientific notes of Berdyansk State Pedagogical University. Series: Pedagogical sciences. Issue 3. P. 102-108.

8. Kostenok P.I., Koniakhina G.P. (2020) Filosofiia bezopasnosti kak metodologicheskogo osnovanie pedagogicheskogo resheniia problem obespecheniia bezopasnosti [Safety philosophy as a methodological basis for the pedagogical solution of safety problems]. Problems of modern education. Vol. 5. P. 19-30.

9. Kostiuk M. (2012) Formuvannia osobystosti bezpechnoho typu povedinky [Formation of personality of safe type of behavior]. Sustainable development - Scientific debut in 2011. Racibórz. P. 269-276.

10. Lapenko T.H. (2017) Motyvatsiia v okhoroni pratsi - tilky prymusom problemy ne vyrishyty [Motivation in labor protection - only by coercion not to solve the problem]. Innovative aspects of labor safety system, protection of intellectual property: materials II All-Ukrainian. scientific-practical internet conference Poltava, March 29-30, 2017. P. 5-8. 
11. Nahaichuk O.V. (2018) Formuvannia kompetentnostei z okhorony pratsi ta bezpeky zhyttiediialnosti $\mathrm{u}$ maibutnikh uchyteliv tekhnolohii $\mathrm{u}$ protsesi fakhovoi pidhotovky [Formation of competencies in occupational safety and health in future teachers of technology in the process of professional training]. Problems of modern teacher training. Vol. 18. P. 241-250.

12. Pulkin M.V. (2017) Fenomen pianstva v XIX nachale XX vv.: problemy osmysleniia (po materialam Evropeiskogo Severa Rossii) [The phenomenon of drunkenness in the 19th and early 20th centuries: problems of comprehension (based on the materials of the European North of Russia)]. Studia Humanitatis. Vol. 4.14 p.

13. Semenets L.M., Vasylieva R.Yu. (2019) Kompetentsii studentiv zakladiv vyshchoi osvity z bezpeky zhyttiediialnosti: zmistovyi aspekt [Competences of students of higher education institutions in life safety: content aspect]. Scientific Bulletin of Uzhhorod University. Series "Pedagogy. Social work". Issue 1 (44). P. $165-168$.

14. Spirina T.P. (2009) Formuvannia profesiinoi kultury maibutnikh sotsialnykh pedahohiv u navchalnovykhovnomu protsesi vyshchoho navchalnoho zakladu [Formation of professional culture of future social pedagogues in the educational process of higher education] (PhD Thesis), 13.00.04. Zhytomyr. $22 \mathrm{p}$.

15. Khrystuk OL. (2012) Problema alkoholnoi adyktsii u suchasni vitchyznianii psykholohii [The problem of alcohol addiction in modern domestic psychology]. Scientific Bulletin of Lviv State University of Internal Affairs. The series is psychological. Issue 2 (2). P. 104-112.

16. Sulima R. (2000) Antropologia codziennosci [Everyday anthropology]. Cracow: Wydawnictwo Uniwersytetu Jagiellonskiego. 194 p. 